Polar Biology

January 2018, Volume 41 Issue 1 Pages 149-162

http://dx.doi.org/10.1007/s00300-017-2178-0

http://archimer.ifremer.fr/doc/00397/50797/

(c) Springer-Verlag GmbH Germany 2017

\title{
A comparison of the trophic ecology of Beaufort Sea Gadidae using fatty acids and stable isotopes
}

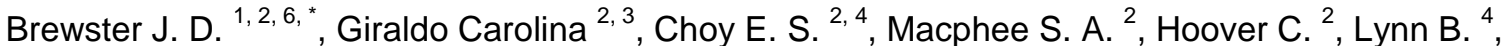 \\ Mcnicholl D. G. ${ }^{2,4}$, Majewski A. ${ }^{2}$, Rosenberg B. ${ }^{2}$, Power M. ${ }^{5}$, Reist J. D. ${ }^{2}$, Loseto L. L. ${ }^{2}$
}

${ }^{1}$ Univ Manitoba, Dept Environm \& Geog, 500 Univ Cres, Winnipeg, MB R3T 2N2, Canada.

${ }^{2}$ Fisheries \& Oceans Canada, Inst Freshwater, 501 Univ Cres, Winnipeg, MB R3T 2N6, Canada.

${ }^{3}$ Ifremer, Lab Ressources Halieut, 150 Quai Gambetta,BP 699, F-62321 Boulogne Sur Mer, France.

${ }^{4}$ Univ Manitoba, Dept Biol Sci, 500 Univ Cres, Winnipeg, MB R3T 2N2, Canada.

${ }^{5}$ Univ Waterloo, Dept Biol, 200 Univ Ave, Waterloo, ON N2L 3G1, Canada.

${ }^{6}$ Fisheries \& Oceans Canada, POB 1871, Inuvik, NT XOE 0TO, Canada.

*Corresponding author : J. D. Brewster, email address : jasmine.brewster@dfo-mpo.gc.ca

\begin{abstract}
:
Polar cod (Boreogadus saida) is one of the most studied Arctic marine fishes given its circumpolar distribution and centralised role in the Arctic marine food web. In contrast, relatively little is known about two other Arctic Gadidae: saffron cod (Eleginus gracilis) and Greenland cod (Gadus ogac). Climate change is expected to have an effect on sea ice-associated species, such as polar cod, but due to our lack of knowledge of other arctic gadid species it remains unclear how climate change will impact them and their interactions within the arctic marine ecosystem. Here, we explored the ecology of three Arctic Gadidae that co-occur in the Canadian Beaufort Sea. Stable isotope (SI) (niche overlap) and fatty acid (FA) (correspondence analysis and linear discriminant analysis) biomarkers were used to assess among- and within-species differences and trophic niche. Despite the close habitat proximity of saffron cod and polar cod while on the shelf, trophic niche characterisation revealed only a marginal overlap. Marginal niche overlaps also occurred for the two coastal species with similar diets, saffron cod and Greenland cod, likely reflecting regional-scale differences between two habitats. Within-species, polar cod collected from three habitats (shelf, upper- and lower-slope habitats) were not differentiated likely due to the movement of individuals between habitats. In contrast, Greenland cod had a narrow trophic niche and differentiation occurred between the two collection sites. The comparison of trophic niches defined by stable isotope and fatty acid proved a promising tool for new insights into the ecology of Arctic fishes.
\end{abstract}

Keywords : Niche overlap, Fatty acids, Stable isotopes, Beaufort Sea, Cod 


\section{Introduction}

Reliable baseline information for Arctic marine food webs is essential for assessing the ecological responses anticipated to occur with climate change (Wassman et al. 2011). While some aspects related to the organisation of Arctic marine food webs are relatively well characterised, including general marine trophic structures, energetic pathways and pelagic-benthic coupling (e.g. Hobson and Welch 1992; Welch et al. 1992; Hobson et al. 1995, 2002; Iken et al. 2005), basic ecological information, including diet and habitat use, is generally lacking particularly for Arctic marine fishes. The paucity of information is in part due to the lack of commercial interest in many Arctic species and the high costs and logistical challenges associated with accessing remote, seasonally ice-covered areas. As a result, sampling effort is typically restricted to the open-water season, and is often limited by temporal and spatial coverage of sea ice.

Adequately characterising marine fish diets and habitat uses is further limited by classical approaches to dietary analyses (e.g. gut content analysis) that provide insights into short-term prey ingestion (i.e. the 'last meal'), biased toward specific prey tissues (i.e. hard parts opposed to soft tissues, Bowen and Iverson 2012), and, therefore, represent only a limited area of habitat (e.g. Iverson et al. 2004; 2007) or temporal profile of prey use (Fry 2006). Ecological biomarkers such as stable isotope (SI) ratios and fatty acids (FA) signatures are powerful tools that have been widely applied over the past decade because they are readily measured, integrate information across ecologically relevant scales, provide understanding of both sources of energy and trophic position, and are sensitive to changes and respond in a predictable manner to those (Post 2002; Iverson et al. 2004; Chouvelon et al. 2015). SI and FA have been applied to studies of various aspects of feeding ecology of Arctic region marine fishes, including: diet, trophic structure, resource partitioning, individual specialisation, and niche segregation (Budget et al. 2002; Iverson et al. 2002; Giraldo et al. 2016; Stasko et al. 2015; Brewster et al. 2016).

Ratios of stable carbon $\left(\delta^{13} \mathrm{C}\right)$ and nitrogen $\left(\delta^{15} \mathrm{~N}\right)$ isotopes are typically applied in trophic ecological studies to determine the contribution of marine and terrestrial food webs to the diet of consumers and/or to estimate trophic position (Post 2002). In marine environments, $\delta^{13} \mathrm{C}$ provides a proxy for foraging habitat (i.e. sources of organic matter), since $\delta^{13} \mathrm{C}$ values change only by a small amount at each trophic level (i.e. $<1 \%$ ). In contrast, $\delta^{15} \mathrm{~N}$ values indicate trophic position because consumers are enriched in ${ }^{15} \mathrm{~N}$ relative to their prey (reviewed in Post 2002; Hussey et al. 2014). A combination of $\delta^{13} \mathrm{C}$ and $\delta^{15} \mathrm{~N}$ values of 
an individual can be used to quantitatively define the 'isotopic niche' of a species (Layman et al. 2007; Newsome et al. 2007). The isotopic niche, however, is unable to distinguish among prey items with similar isotopic signatures (Newsome et al. 2007).

FA analyses can provide information on the composition of predator diets and indicate foraging strategies (benthic versus pelagic), since consumers assimilate dietary characteristics of essential FA from their prey (Iverson et al. 2004; Tucker et al. 2008). FA signatures integrate consumers' diets over a period of several weeks (Iverson et al. 2004; Budge et al. 2006). Therefore, the combined use of SI and FA provide multiple lines of evidence for the feeding ecology of marine fishes that helps define trophic niches (i.e. sources of prey and trophic positions of both prey and predator) to facilitate inferences regarding the general diets of species (El-Sabaawi et al. 2009; Connelly et al. 2014).

The diversity of habitat use by three Arctic species of Gadidae: polar cod (Boreogadus saida), Greenland cod (Gadus ogac), and saffron cod (Eleginus gracilis) are shown in the distribution of these species in offshore marine and coastal environments of the Beaufort Sea (Nielsen and Andersen 2001; Johnson et al. 2009; Walkusz et al. 2013). Polar cod is perhaps the most well-studied Arctic marine fish and is known to play a central role in the marine ecosystem as prey for marine mammals and birds (Bradstreet and Cross 1982; Welch et al. 1993; Loseto et al. 2009; Walkusz et al. 2013). This species is widely distributed throughout the Arctic Ocean (Mecklenburg et al. 2011) and occurs in a broad range of habitats within the Beaufort Sea, from shallow coastal areas (Crawford and Jorgenson 1996; Parker-Stetter et al. 2011) to the continental shelf and slope (Rand and Logerwell 2010; Crawford et al. 2012; Majewski et al. 2016b, 2017). In contrast to the broad range of habitats occupied by polar cod, saffron cod and Greenland cod exhibit a primarily benthic feeding strategy and are generally restricted to coastal habitats. Within the Beaufort Sea, saffron cod are widely distributed along the coastal mainland and are locally abundant nearshore, typically at depths less than 50m depths (Bond and Erickson 1989, 1993; Griffiths et al. 2008). Greenland cod are sporadically distributed in Arctic and subarctic waters within Canada and Greenland and are typically associated with coastal areas (Morin et al. 1991; Nielsen and Andersen 2001), although they do occur over deep waters (Coad and Reist 2004). Here we explore diversity in trophic niches of three Arctic Gadidae and demonstrate the utility of the application of ecological biomarkers to discriminate between their trophic niches. 
Given the differences in the life-history, habitat, and likely also subsequent prey-use of these species, we used SI and FA to: (1) evaluate among-species differences in trophic niche for polar cod, saffron cod, and Greenland cod collected from coastal habitats, <200m in depth; (2) identify among-habitat differences in the trophic niche of polar cod (shelf, upper-slope, lower-slope); and, (3) assess spatial variability in Greenland cod trophic niche by studying differences in trophic niches between sites within coastal environments.

\section{Materials and methods}

\section{Study Area and Fish Collections}

Samples were collected from the Canadian Beaufort Sea (CBS) offshore continental shelf, slope and three coastal areas: Shingle Point, Ulukhaktok and Sachs Harbour (Table 1; Fig 1) in the Inuvialuit Settlement Region of the western Canadian Arctic. The study areas included dynamic environments that were classified into three habitat groups: coastal-estuarine habitat (Shingle Point), coastal-marine habitats (Sachs Harbour and Ulukhaktok), and offshore-marine habitats (Beaufort Sea-depth). The coastal-estuarine habitat of saffron cod was differentiated from the coastal-marine habitat of Greenland cod by the large freshwater influence of the Mackenzie River (i.e. Mackenzie estuary) on the Shingle Point coastal system (Carmack and Macdonald 2002). Fish were collected from several sampling programs: saffron cod were collected from the coastal research program (Arctic Coastal Ecosystem Study (ACES)). Greenland cod were collected from a community based fish collection program (Sachs Harbour and Ulukhaktuk collections), and the offshore program (Beaufort Sea Marine Fishes Project (BSMF project)) collected polar cod (Majewski et al. 2016a). All collections occurred in the open water season of 2012. Polar cod were collected at 26 stations that covered three habitat areas in the CBS: the shelf (15-220m), the upperslope $(>220-510 \mathrm{~m})$, and the lower-slope $(>510-800 \mathrm{~m})$. Polar cod were collected by trawling that was conducted using a modified Atlantic Western IIA otter trawl net (codend mesh size of 0.5 inches) deployed from the F/V Frosti (see Majewski et al. 2016b). Saffron cod were collected at a coastal station on Shingle Point (Fig 1). Gill net bycatches from subsistence fishering and beach seines were used to sample saffron cod from mid-July to early-August in 2012. Lastly, Greenland cod were collected from the coastal environments of Ulukhaktok and Sachs Harbour. Sampling was conducted by community members using 
jiggling rods through the ice near to the communities. These collections were opportunistic and typically occurred between June and July 2012. All samples were vacuum sealed, packaged frozen $\left(-18^{\circ} \mathrm{C}\right)$, and sent to Fisheries and Oceans Canada laboratory in Winnipeg Manitoba to be processed for biological data and tissue sampling for FA and SI analyses (Table 1).

Fatty acid analysis

Semi-frozen fish samples were cut in half lengthwise along the medial plane and the gastrointestinal tract (i.e. stomach and contents, and intestines) were removed, although not further analysed. Half the remaining fish carcass was ground in a Retsch GM200 grinder in a semi-frozen state, then re-frozen and stored at $-80^{\circ} \mathrm{C}$ before being freeze dried in a Labconco Freezone 18 freeze drier. Lipids were extracted from $0.25 \mathrm{~g}$ of the freeze-dried fish using 2:1 chloroform-methanol containing $0.01 \%$ butylated hydroxytoluene (BHT) (v/v/w) (Folch et al. 1957). The lipid phase was filtered, collected, and dried with anhydrous sodium sulphate and evaporated under nitrogen to obtain the total lipid weight. The fatty acid methyl esters (FAMEs) were prepared from the extracted lipid by transesterification with Hilditch reagent ( $0.5 \mathrm{~N} \mathrm{H}_{2} \mathrm{SO}_{4}$ in methanol) (Morrison and Smith 1964). The samples were then heated for $1 \mathrm{~h}$ at $100^{\circ} \mathrm{C}$, and gas chromatography (GC) was performed on an Agilent Technologies 7890N GC equipped with a $30 \mathrm{~m} \mathrm{~J} \& W$ DB-23 column. The GC was coupled to a Flame Ionization Detector (FID) operating at $350^{\circ} \mathrm{C}$. Agilent Technologies ChemStation software was used to quantify peaks. Standards were obtained from Supelco (37 component FAME mix) and Nuchek (54 component mix GLC-463). A total of 75 FAMEs were identified for the three species of cod, with the 30 FA (representing >99\% of total FA) used to identify general diet patterns reported as percent of total FA (\%FA, Table 3$)$. The signatures of FA 20:1n9 and 20:1n11, as well as 22:1n9 and 22:1n11, were summarised in pairs as $\Sigma \mathrm{C} 20+22$ monounsaturated FA (MUFA), respectively (Table 3). The following FA (or combination of FA) were used as trophic markers: Calanus-type markers were defined as $\sum$ C20 +22 MUFA (e.g. Falk-Petersen et al. 2002). Strong influences of nearshore (i.e. terrestrial influences) benthic feeding have been identified through high proportions of 18:3n3 and 18:2n6 FA (Budge and Parrish 1998; Tocher 2003). The remaining 18 polyunsaturated FA and 20 polyunsaturated FA were grouped into the indicators 18PUFA and 20PUFA (Tocher 2003, 2010; Legezynska et al. 2014). 


\section{Stable isotope analyses}

Muscle tissue samples were taken from the dorsal area (remaining half fish), oven-dried $\left(40^{\circ} \mathrm{C}\right)$, then ground into powder using a mortar and pestle, weighed, and packed into tin capsules. Samples were analysed using a Thermo-Finnigan Delta Plus continuous flow isotope mass spectrometer (Thermo Finnigan, Bremen, Germany) coupled to a 4010 Elemental Analyzer (Costech International S. p. A., Milan Italy) at the University of Waterloo Environmental Isotope Laboratory. Analytical precision was $\pm 0.1 \%$ o and $\pm 0.2 \%$ for $\delta^{13} \mathrm{C}$ and $\delta^{15} \mathrm{~N}$, respectively, and was determined by repeat analysis of duplicates (one in ten). All resulting measurements were expressed using standard delta $(\delta)$ notation as parts per thousand differences (\%) with respect to the international reference standards, carbonate rock from the Pee Dee Belemnite formation for $\delta^{13} \mathrm{C}$ (Craig 1957) and nitrogen gas in the atmosphere for $\delta^{15} \mathrm{~N}$ (Mariotti 1983). Analytical accuracy was validated against internal laboratory standards cross-calibrated against the International Atomic Energy Agency standards $\mathrm{CH}_{6}$ for carbon and $\mathrm{N} 1$ and $\mathrm{N} 2$ for nitrogen.

\section{Statistical Analysis}

For this study only adult, non-spawning individuals were analysed. Adult life-stage was determined using published age or length and maturity data. Only polar cod individuals aged 2+ (Craig et al. 1982; Gallaway and Norcross 2011) and larger individuals (fork length >300mm) of saffron cod and Greenland cod classified as adults on the basis of published age-size relationships (Morin et al. 1991; Johnson 1995; Gallaway and Norcross 2011) were used in this study (Table 1). Spawning status was determined by visual inspection and presence of gonads. Because lipids are depleted in ${ }^{13} \mathrm{C}$, variation in the lipid content among species can significantly affect $\delta^{13} \mathrm{C}$ values ( 3-4\%, Post et al. 2007). We accounted for the variation in lipid content by calculating the carbon to nitrogen $(\mathrm{C}: \mathrm{N})$ ratio for each sample, and applied a correction equation (Post et al. 2007; Mintenbeck et al. 2008):

$$
\delta{ }^{13} \mathrm{C}_{\text {normalised }}=\delta{ }^{13} \mathrm{C}_{\text {untreated }}-3.32+0.99 * \mathrm{C}: \mathrm{N}
$$

As length is often related to $\delta^{15} \mathrm{~N}$ trophic enrichment in fish (Romanuk et al. 2011), the relationship between $\delta^{15} \mathrm{~N}$ and fork length (FL) was examined using linear regression for each species (polar cod (Linear Regression, $\delta^{15} \mathrm{~N}=25.75 * \mathrm{FL}-255.85, R^{2}=0.60, d f=66, t=9.98, p<0.0001$ ), Greenland cod (Linear Regression, $\delta^{15} \mathrm{~N}=39.77 * \mathrm{FL}-208.96, R^{2}=0.51, d f=65, t=8.28, p<0.0001$ ), and Saffron cod 
(Linear Regression, $\delta^{15} \mathrm{~N}=16.77 * \mathrm{FL}+182.08, R^{2}=0.20, d f=36, t=3.02, p=0.004$ ). The regression residual for each individual within a species was calculated and added to the species-specific means to standardise data for size (Swanson and Kidd 2010).

For comparisons among species, only polar cod collected on the shelf were compared to the coastal species saffron cod and Greenland cod. Statistical analyses related to FA and SI were conducted in R ver. 3.1.0 (R Core Team 2012). For SI, ellipses were generated using the R package nicheROVER (Swanson et al. 2015). We calculated the $40 \%$ isotopic ellipse areas for each species, and used it to evaluate the niche of each species (using $40 \%$ of the data for each species). NicheROVER was also used to calculate the probability of niche overlap among species (Swanson et al. 2015), and is reported as mean percent with $2.5 \%$ and $97.5 \%$ confidence intervals $(\mathrm{CI})$ (mean $\%[\mathrm{CI}=2.5 \%, 97.5 \%])$. The $40 \%$ isotopic ellipse area or 'niche size' was evaluated using $\delta^{13} \mathrm{C}$ and $\delta^{15} \mathrm{~N}$ range $\left(\delta^{13} \mathrm{CR}\right.$ and $\left.\delta^{15} \mathrm{NR}\right)$ values of individuals within each species (Table 2). The $40 \%$ data was used to mitigate the influence of extreme $\delta^{13} \mathrm{C}$ and $\delta^{15} \mathrm{~N}$ values on the analysis (Jackson et al. 2011). The Residual Permutation Procedure (RPP) was performed among the three species of cod to determine variation among species using $\delta^{13} \mathrm{C}$ and $\delta^{15} \mathrm{~N}$ as response variables, and using mean distance (MD) as a proxy of mean isotopic differences and niche diversity. Specifically, Euclidian distances between species' centroids (defined by mean values of $\delta^{13} \mathrm{C}$ and $\delta^{15} \mathrm{~N}$, MD) were calculated and used to determine if species were significantly different from one another (Turner et al. 2010). Additionally, niche size was calculated and used as a metric of individual dispersion that can be compared among species.

Correspondence analysis (Benzécri 1992) was chosen to compare FA profiles among species using the R packages $c a$ and ggord. Distances among FA profiles were computed with Chi-square metrics so relationships between individuals (observations) and FA (descriptors) could be viewed on a twodimensional plane (ordination). The correspondence analysis was performed on the proportions of FA among the three species, examining 31 FA for 116 individuals. A linear discriminant analysis (LDA) was performed on the FA compositions of Greenland $\operatorname{cod}(n=66)$ and polar cod $(n=70)$, followed by a MANOVA, to determine if individuals of the same species from different locations could be differentiated depending on feeding habitats. The proportions of fatty acid signatures were normalised using a log transformation prior to LDA (Aitchison 1986). 


\section{Results}

Among-species comparison: isotopic niche overlap

Overall, the locations of niche centroids (mean SI signatures) within bivariate isotopic space differed among the three species (MD, $p=0.001)$. Mean $\delta^{13} \mathrm{C}$ for polar cod, Greenland cod and saffron cod were $\bar{x} \pm \mathrm{SE}=-23.50 \pm 0.15 \%, n=12 ; \bar{x}=-21.76 \pm 0.08 \%$ o, $n=66$; and $\bar{x}=-22.88 \pm 0.05 \%$ o, $n=38$, , respectively, where the overall difference in mean $\delta^{13} \mathrm{C}$ expressed in the three cod species was $1.74 \%$ (Table 1). A maximum $\delta^{13} \mathrm{C}$ difference of $4.24 \%$ was observed when considering the lowest and highest polar cod (-24.22\%o, captured on the shelf) and Greenland $\operatorname{cod}\left(-19.98 \%\right.$ ) isotopic values. Mean $\delta^{15} \mathrm{~N}$ values for the three gadids were as follows: for polar cod, $\bar{x} \pm \mathrm{SE}=14.93 \pm 0.07 \%, n=12$; for Greenland $\operatorname{cod}, \bar{x} \pm \mathrm{SE}=15.34 \pm 0.07 \%$ o, $n=66$; and for saffron cod, $\overline{\boldsymbol{x}} \pm \mathrm{SE}=15.18 \pm 0.08 \%, n=38$ (Table 1$)$. The $\delta^{15} \mathrm{NR}$ expressed in the muscle tissue of polar cod (captured on the shelf, 1.78\%o), Greenland cod (2.86\%o), and saffron cod $(2.57 \%$ ) indicated individuals fed at a common trophic level within and among species (Table 1). Greenland cod isotopic niche size was marginally larger (niche size $=1.69$ ) than polar cod (niche size $=0.91)$, and saffron cod $($ niche size $=0.60)($ Figure 2$)$.

The largest probability of niche overlap was observed between saffron cod and that of shelfcaptured polar cod (Table 2). The observed $\delta^{13} \mathrm{C}$ values of polar cod and saffron cod were more negative compared to Greenland cod, resulting in the lowest probability of niche overlap between polar cod and saffron cod with the niche of Greenland cod (niche overlap $=0.28 \%$ and $1.06 \%$, respectively, Table 2 ).

\section{Similarity of dietary patterns among-species: comparison of FA profiles}

The first dimension of the correspondence analysis explained $50.99 \%$ of the variance, whereas the second dimension explained $20.68 \%$, for an overall total of $71.67 \%$ (Table 3, Figure 3). The first dimension demonstrated the most among-species variance and was characterised by the FA $\Sigma$ C22 MUFA, 22:6n3, and $\sum$ C20 MUFA (FA are listed from greatest to smallest contribution, respectively). The second dimension was characterised by 16:1n7, $\Sigma$ C22 MUFA, 22:6n3, and 18:1n9. Polar cod was separated from the other species along the first axis and were characterised by high levels of $\Sigma \mathrm{C} 20+22$ MUFA (Calanustype marker) and 22:1n7. There was greater overlap between saffron cod and Greenland cod (high proportions of 18:3n3, 18:2n6, 22:6n3 and 22:5n3) than of either with polar cod. Greenland cod were 
further characterised by 20:4n6, and saffron cod were characterised by higher proportions of 16:1n7 (Table $3)$.

Isotopic and FA variation within-species: Greenland cod among sites

In coastal environments Greenland cod collected from Sachs Harbour had marginally lower $\delta^{13} \mathrm{C}$

$(\overline{\boldsymbol{x}} \pm \mathrm{SE}=-21.91 \pm 0.09 \%, n=41)$ and $\delta^{15} \mathrm{~N}$ values $(\overline{\boldsymbol{x}}=14.93 \pm 0.09 \%, n=41)$ compared to Ulukhaktok individuals $\left(\overline{\boldsymbol{x}}=\delta^{13} \mathrm{C}:-21.15 \pm 0.13 \%, n=25, \delta^{15} \mathrm{~N}: 16.00 \pm 0.13 \%, n=25\right)$. Niche centroids of Greenland cod from the two locations differed significantly (MD, $p=0.001$, although niche sizes (Figure 4a) were similar (Ulukhaktok niche size $=0.86$, Sachs Harbour niche size $=0.97$ ). The niche of Greenland cod individuals collected from Sachs Harbour had less probability of overlap with the niche of Ulukhaktok individuals in contrast to the reverse for the comparison of Ulukhaktok with Sachs Harbour (Table 3).

For Greenland cod, one discriminant function was generated and accounted for $100 \%$ of the variance. The LDA plot of the mean scores of the discriminant function showed that Greenland cod had distinct FA compositions (MANOVA, Wilks' $\lambda=0.17, p=0.0003$, percentage of misclassification 2.9\%) between sampling sites (Ulukhaktok or Sachs Harbour) (Figure 4b). The Greenland cod positioned to the right (+) of the LDA were primarily individuals from Ulukhaktok characterised by high proportions of 22:5n6, 18:2n4, and low 16:1n7 compared to the individuals from Sachs Harbour, positioned on the left (-) and characterised by higher proportions of 18:1n7, 18:2n6, and 21:5n3 (Figure 4b).

Isotopic and FA variation within-species: polar cod across sites.

The $\delta^{13} \mathrm{C}$ and $\delta^{15} \mathrm{~N}$ values of polar cod from the three offshore habitats (shelf, upper-slope and lower-slope $)$ yielded trophic niches of similar size: shelf $=0.91(n=12)$, upper-slope $=0.86(n=40)$, and lower-slope $=1.07(n=18)($ Figure 5$)$. The niche centroid positions of the three habitats did not differ significantly (MD, $p>0.47$, for all). Polar cod individuals collected on the shelf had the highest niche overlap with those from the upper-slope (Table 3). Higher overlaps were observed between the niches of lower-slope and upper-slope caught fish (Table 3). The lowest probabilities of overlap observed among individuals of polar cod were observed in the niches of upper-slope and lower-slope individuals with the shelf niche (Table 3). 
The first discriminant function for polar cod accounted for 53.78\% of the variance, and separated polar cod from the shelf and lower-slope habitats from individuals from the upper-slope. The second discriminant function accounted for $46.22 \%$ of the variance, and indicated some overlap between polar cod found in the upper-slope with those from lower-slope habitats. The FA influencing the discrimination on the first dimension were 16:0, 16:2n4, 18:2n6, $\Sigma$ C22 MUFA, 16:1n7 (Figure 6a). The FA that influenced the second dimensions the most were 18:2n6, $\Sigma \mathrm{C} 22$ MUFA,18:1n5, and 18:3n3 (Figure 6b). The results of the LDA, where 41 individuals (57.75\%) were misclassified, indicated that the three depth habitats (shelf, upper-slope, and lower-slope) did not explain variation in fatty acid composition of polar cod (MANOVA, Wilks' $\lambda=0.25, p=0.14$ ) particularly well. Thus, polar cod that occupy different depths (shelf, upper-slope, and lower-slope) were not discriminated by diet inferred from FA.

\section{Discussion}

Here we assessed the among- and within- species trophic niche differences in three Arctic gadid species occurring in the Beaufort Sea. Using SI and FA biomarkers, our trophic niche characterization found that among-species, polar cod overlapped marginally with saffron cod when on the shelf. Withinspecies comparisons demonstrated that trophic niches of polar cod could not be discriminated among different depth groups, whereas, Greenland cod had variations in habitat-use and diet indicators.

\section{Among-species habitat comparison: isotopic niche overlap}

Trophic niches among the three gadid showed little overlap. Variations in isotopic niche breadth along the carbon axis were observed among offshore and coastal cod species, as well as among cods captured at different coastal sites. Niches of shelf-caught polar cod and saffron cod overlapped the most that is largely explained by a period of shared habitat and resources during summer (Majewski et al. 2006). Among the Beaufort Sea Gadidae, polar cod was the most depleted in ${ }^{13} \mathrm{C}$ when compared to coastal cod species. Depletion in ${ }^{13} \mathrm{C}$ values is characteristic of pelagic foraging strategies where phytoplankton production is the primary source energy in the food chain. This depletion associated with pelagic feeding strategies (Hobson et al. 2002) could influence the ${ }^{13} \mathrm{C}$-depleted values observed in polar cod, thus offshore pelagic feeding fishes would be expected to have lower $\delta{ }^{13} \mathrm{C}$ compared to coastal cod species with benthic 
feeding strategies (where benthic algae and detritus influence the base of the food chain, Post 2002). Conversely, marine derived source carbon (i.e. phytoplankton) has been reported to be less depleted/more positive (> -25.5) compared to that of terrestrial carbon (<-25.5) (Dunton et al. 2012). The significant discharge of terrestrial carbon delivered to coastal habitats from the Mackenzie River (Stein and Macdonald 2004) is depleted in ${ }^{13} \mathrm{C}$ (Saupe et al 1989; Dunton et al. 2006), and has been report to integrate into some marine organisms such as benthic species, zooplankton, and bowhead whales feeding in the region (Dunton et al. 1989; Saupe et al. 1989; Schell et al. 1989). Though, the integration and importance of terrestrial carbon to pelagic and offshore species, such as anadromous fish, is not well characterised in the Beaufort Sea (but see Dunton et al. 2006; Von Biela et al. 2012; Divine et al. 2015). While our results demonstrate the importance of vicinity to the Mackenzie River in coastal fish our findings also demonstrate a coastal and offshore difference, where coastal fishes had more enriched (Greenland cod and saffron cod) relative to more depleted ${ }^{13} \mathrm{C}$ in offshore species (polar cod), thus tending to support Hansen et al.(2012). A better understanding of the assimilation processes of terrestrial ${ }^{13} \mathrm{C}$ from the benthos to pelagic species in coastal marine systems is needed to understand the isotopic differences observed between coastal and offshore fish, additionally characterizing the influence Mackenzie River source of depleted ${ }^{13} \mathrm{C}$ on nearshore marine species is needed.

Despite saffron cod and Greenland cod being coastal species and their previously described diet of primarily epi-benthic fishes (Nielsen and Andersen 2001), their isotopic niches only marginally overlapped. We expect that the large influence of freshwater outflow from the Mackenzie River (where saffron cod was captured), which delivers a significant source of carbon, depleted in ${ }^{13} \mathrm{C}$ into the coastal habitat (Stein and Macdonald 2004) to be reflected in the prey of saffron cod. Thus depletion of ${ }^{13} \mathrm{C}$ values in saffron cod that were captured in the coastal-estuarine habitat is expected, relative to the coastal-marine environments of Sachs Harbour and Ulukhaktok that are far removed from the Mackenzie River outflow. We recognize that isotopic variations among species may also be impacted by species-specific factors (e.g. diet, assimilation of $\delta^{13} \mathrm{C}$ into tissues, Hobson et al. 2002); however, similar foraging strategies between Greenland and saffron cods suggest that differences in habitat (coastal-marine versus coastal-estuarine) are influencing the SI variations between these species. 


\section{Among-species feeding strategies comparison: fatty acid}

The first dimension of the correspondence analysis was consistent with a pelagic-benthic gradient, where species were differentiated depending on their levels of Calanus-type markers (pelagic) and benthic algal biomarkers (20:4n6). Polar cod was the species with the higher proportion of Calanus-type markers indicating pelagic marine feeding (Falk-Petersen et al. 2002). Feeding on copepods by polar cod accords with previous studies where copepod species have been found to be the dominant prey in the stomach contents of demersal juvenile and adult polar cod from the Beaufort Sea (Walkusz et al. 2013; Majewski et al. 2016b). This finding corresponds with lower $\delta^{13} \mathrm{C}$ values characteristic of pelagic feeding (Hobson et al. 2002). Although a high prevalence of zooplankton in the diet of polar cod has been reported, generalistfeeding strategies with heavy reliance on Themisto and Calanus prey are known (Walkusz et al. 2013; Majewski et al. 2016b). Variable diets influenced by predator size have also been identified (Gray et al. 2016; Majewski et al. 2016b; Marsh et al. 2017). Narrow pelagic feeding strategies relying on copepods are observed in smaller polar cod $(<70 \mathrm{~mm})$ in comparison to those of larger individuals $(>70 \mathrm{~mm})$ whose diet extends to include benthic prey (Gray et al. 2016). In the present study smaller polar cod $(\overline{\boldsymbol{x}} \pm \mathrm{SD}=\mathrm{FL}$ : $108.20 \pm 6.83 \mathrm{~mm}, n=12$ ) were collected on the shelf; the niche of these individuals overlapped with saffron cod. The incorporation of benthic feeding on invertebrates in polar cod could explain similar $\delta^{15} \mathrm{~N}$ to benthic-feeding saffron cod and Greenland cod, and $\delta^{15} \mathrm{~N}$ values consistent with feeding approximately two trophic levels higher than reported in Calanus copepods (Stasko et al. 2016).

The FA-inferred diets of saffron and Greenland cods did not significantly differ, suggesting that both species had similar feeding ecologies in these two habitats. Although saffron and Greenland cod shared similar FA signatures, higher values of 20:4n6 indicating influences from benthic invertebrate prey (e.g. amphipods, Connelly et al. 2014) for some individuals of Greenland cod were observed compared to saffron cod. Stomach content analysis of saffron cod in the CBS identified crustaceans and fish as prey (Lacho et al. 1991). Previous research on Greenland cod stomach contents and isotopic analyses have indicated Greenland cod feed on smaller benthic fish species, such as capelin, crustaceans, molluscs, echinoderms, and polychaetes (e.g. Morin et al. 1991; Nielsen and Andersen 2001; Knickle et al. 2014),, and this was reflected here in the more variable FA composition. Similar mean $\delta^{15} \mathrm{~N}$ and $\delta^{15} \mathrm{NR}$ indicated consistent trophic level feeding within the Greenland cod species, whereas $\delta^{15} \mathrm{~N}$ values did not differ from 
those observed in saffron cod. For instance, $\delta^{15} \mathrm{~N}$ of brittle stars collected from the nearshore shelf (10.40\%o), offshore shelf (11.73\%o), upper-slope (12.42\%o) and lower slope (12.12\%o) habitats (Stasko et al 2016), in addition to $\delta^{15} \mathrm{~N}$ values observed in molluscs $\left(\delta^{15} \mathrm{~N}\right.$ ranging from $8.5-12.7 \%$ ), polychaetes $\left(\delta^{15} \mathrm{~N}\right.$ $=12.3 \%$ ) , and crustaceans $\left(\delta^{15} \mathrm{~N}\right.$ ranging from 9.2-11.4\%o) (Hobson et al. 2002) results indicate consistent feeding approximately one to two trophic levels lower then suspected predators, saffron cod (15.18\%o) and Greenland cod (15.34\%). Enriched ${ }^{13} \mathrm{C}$ values indicative of benthic feeding (Hobson et al. 2002; Divine et al. 2015), and a diet dominated by benthic invertebrates parallels the higher contribution of benthic FA found in Greenland and saffron cods compared to polar cod.

\section{Within-species comparison: polar cod habitat and diet overlap}

Analyses of FA (LDA) and SI (niche overlap) of polar cod indicated that the habitat and diet did not significantly differ among locations, since isotopic niches and FA profiles could not be differentiated among polar cod collected on the shelf, upper-slope and lower-slope. However, polar cod displayed the most variability in FA among species, as some individuals were characterised by FA 22:1n7 and 20:1n7, FA markers elevated in some bivalves and elevated 22:1n7 found in benthic feeding fish (Giraldo et al. 2016). The LDA did show that polar cod were characterised by Calanus-markers ( $\Sigma$ C20 +22 MUFA), 16:1n7, and dinoflagellate (22:6n3, 18 polyunsaturated FA and 16:0) markers. Sedimentation of diatoms to the benthos of coastal environments has been shown to influence benthic consumer tissues through high proportions of 16:1n7 found in benthic species in Arctic coastal habitats (Graeve 1997; Giraldo et al. 2016). Since FA can reflect the diets of fish over a time frame of several weeks to months, the FA signal suggests polar cod feed on prey from different depths (pelagic and benthic), causing the signal to be indistinct, thus prey sources cannot be distinguished for these sampling locations.

Furthermore, the niche sizes or trophic dispersion of polar cod captured from the shelf, upperslope, and lower-slope did not differ, suggesting polar cod from different depths have similar feeding strategies. These results agree with previous stomach analyses completed for adult polar cod that have indicated calanoid copepods and crustaceans (i.e. amphipods) are the predominant prey in the CBS (e.g. Walkusz et al. 2013; Majewski et al. 2016b) and elsewhere in the Arctic (e.g. Christiansen et al. 2012; Matley et al. 2013). Polar cod collected from the three depths also could not be differentiated using $\delta^{13} \mathrm{C}$ 
and $\delta^{15} \mathrm{~N}$. The similar SI values and ranges suggest similar diets across adult Arctic Cod sampled from the three distinct habitats (see Majewski et al. 2016b). Polar cod are highly mobile and occupy a variety of habitats that vary with respect to water mass structure (i.e. Mackenzie River discharge, polar mixed layer, Pacific and Atlantic water masses) that have distinctive chemical and temperature profiles (e.g. Majewski et al. 2016b). They have also been documented to perform diel vertical migration, potentially feeding on food sources from different water mass habitats within a single day (Benoit et al. 2010; Geoffroy et al. 2015). High spatial variability in spatial habitat use and opportunistic feeding likely hampered the ability to differentiate trophic niche within this species.

Within-species comparison: Greenland cod habitat and diet overlap

The FA signatures of Greenland cod discriminated between fish collected from Ulukhaktok and Sachs Habour. Sachs Harbour Greenland cod feeding in the benthos of freshened habitats was indicated through high proportions of 18:2n6 and 18:3n3 (FA profiles associated with green algae and vascular plants, Kelly and Scheibling 2012) and high proportions of 16:1n7, a FA profile associated with benthic feeding (Graeve 1997; Giraldo et al. 2016), compared to Greenland cod captured at Ulukhaktok. This signal may reflect freshwater outflow from the Sachs River into Sachs Harbour where samples were taken for this study. In contrast, the nearest significant freshwater source near Ulukhaktok, the Kuujjua River, empties north into Minto Inlet, away from the community and the site where cod were opportunistically collected.

Greenland cod from the two locations shared similar $\delta^{13} \mathrm{C}$ values and niche size, indicating some similarities in feeding environments. Still, individuals collected from Ulukhaktok exhibited slightly higher $\delta^{13} \mathrm{C}$ values compared to those from Sachs Harbour. Greenland cod is widely distributed in coastal waters of the Canadian Arctic (Coad and Reist 2004), and appears to exhibit some variability in niche breadth over its range. Thus, further research is needed to identify if this isotopic variation is driven from a habitatspecific source or dietary source. Overall ecological biomarkers SI and FA were able to differentiate the trophic niches of Greenland cod collected from two locations within coastal habitats. 


\section{Conclusions}

Overall, species isotopic niches generated within species coincided with the dietary patterns indicated by FA profiles. Differences in the isotopic niches and FA composition among polar cod, Greenland cod, and saffron cod were indicative of dietary differences consistent with known feeding strategies and published prey types. The variation in isotopic signatures and FA profiles for Greenland cod collected from two coastal locations was sufficient to identify differences in trophic niches that reflect differences in diet and/or habitat use. In contrast, there were no significant differences in isotopic and FA composition for polar cod sampled from the shelf, upper-slope, and lower-slope, despite differences in water mass structure that influence oceanography (e.g. temperature, salinity) and prey compositions across these habitats. The habitat overlap and mobility of polar cod appears to limit abilities to delineate the trophic niche of this species, among areas and habitat despite this species occupying wide variety of habitats over short time periods (i.e. seasons). As the Arctic continues to change and new stressors occur with the decrease in sea ice extent (e.g. Arrigo et al. 2008; Barber et al. 2012), understanding the niche partitioning and behaviours of Beaufort Sea fishes will be essential for monitoring the health of the ecosystem. Understanding how key species such as polar cod, and lesser known species ( i.e. Greenland and saffron cod), will adapt their trophic patterns to the changing Arctic requires an improved understanding of habitat and diet use, particularly during the ice-covered seasons. 


\section{Acknowledgments}

The writing of this manuscript could not have happened without the sampling efforts and collaboration with the Inuvik and Aklavik monitors and families at Shingle Point, and local Ulukhaktok and Sachs Harbour harvesters. We thank the Aklavik Hunters and Trappers Committee, Fisheries Joint Management Committee, Fisheries and Oceans Canada (DFO), Beaufort Regional Environmental Assessment (BREA, INAC) and ArcticNet for financial support. We thank all those who provided sampling support for this study including DFO technicians and employees. We also thank the technicians from the University of Waterloo Ontario, and Freshwater Institute Winnipeg Manitoba who provided laboratory support for SI and FA, respectively. We thank the editor and reviewers for their insight and comments that helped improve this manuscript. 


\section{References}

Aitchison J (1986) The statistical analysis of compositional data. Monographs on Statistics and Applied Probability. London Chapman and Hall

Arrigo KR, Dijken G van, Pabi S (2008) Impact of a shrinking Arctic ice cover on marine primary production.Geophys Res Lett 35:1-6

Barber DG, Asplin MG, Papakyriakou TN, Miller L, Else BGT, Iacozza J, Mundy CJ, Gosslin M, Asselin NC, Ferguson S, Lukovich JV, Stern G, Gaden A, Pućko M, Geilfus NX, Wang F (2012) Consequences of change and variability in sea ice on marine ecosystem and biogeochemical processes during the 2007-2008 Canadian International Polar Year program. Clim Change 115:135159

Benoit D, Simard Y, Gagné J, Geoffroy M, Fortier L (2010) From polar night to midnight sun: Photoperiod, seal predation, and the diel vertical migrations of polar cod (Boreogadus saida) under landfast ice in the Arctic Ocean. Polar Biol 33:1505 - 1520

Benzécri JP (1992) Correspondance Analysis Handbook. Marcel Dekker, New York

Bond WA, Erickson RN (1989) Summer studies of the nearshore fish community at Phillips Bay, Beaufort Sea coast, Yukon. Can Tech Rep Fis Aquat Sci 1676: vi + 102 p

Bond WA, Erickson RN (1993) Fisheries investigations in coastal waters of Liverpool Bay, Northwest Territories. Can Manuscr Rep Fish Aquat Sci. 2204: vi + 51 p

Bowen WD, Iverson SJ (2012) Methods of estimating marine mammal diets: A review of validation experiments and sources of bias and uncertainty. Mar Mammal Sci 29:719-754. doi: $10.1111 / \mathrm{j} .1748-7692.2012 .00604 . \mathrm{x}$ 
Bradstreet MSW, Cross WE (1982) Trophic Relationships at High Arctic Ice Edges. Arctic 35:1-12. doi: $10.1016 / 0266-9838(93) 90013-8$

Brewster JD, Giraldo C, Swanson H, Walkusz W, Loewen TN, Reist JD, Stern GA, Loseto LL (2016) Ecological niche of coastal Beaufort Sea fishes defined by stable isotopes and fatty acids. Mar Ecol Prog Ser 559:159-173. doi: 10.3354/meps11887

Budge SM, Iverson SJ, Bowen WD, Ackman RG (2002) Among- and within-species variability in fatty acid signatures of marine fish and invertebrates on the Scotian Shelf, Georges Bank, and southern Gulf of St. Lawrence. Can J Fish Aquat Sci 59:886-898

Budge SM, Iverson SJ, Koopman HN (2006) Studying Trophic Ecology in Marine Ecosystems Using Fatty Acids: a Primer on Analysis and Interpretation. Mar Mammal Sci 22:759-801. doi:10.1111/j.17487692.2006.00079.x

Budge SM, Parrish CC (1998) Lipid biogeochemistry of plankton, settling matter and sediments in Trinity Bay, Newfoundland. II. Fatty Acids. Org Geochem 29:1531-1545. doi: 10.1016/S0146 6380(98)00176-4

Carmack EC, Macdonald RW (2002) Oceanography of the Canadian shelf of the Beaufort Sea: A setting for marine life. Arctic 55:29-45. doi: 10.1126/science.100.2596.291

Chouvelon T, Caurant F, Cherel Y, Simon-Bouhet B, Spitz J, Bustamante, P (2014) ICES. doi:10.1093/icesjms/fst199

Christiansen JS, Hop H (2012) Trophic ecology of sympatric Arctic gadoids, Arctogadus glacialis (Peters, 1872) and Boreogadus saida (Lepechin, 1774), in NE Greenland. Polar Biol 35:1247-1257

Coad BW, Reist JD (2004) Annotated list of the Arctic Marine Fishes of Canada. Can MS Rep Fish Aqua Sci 2674: iv + 112 p 
Cobb D, Fast H, Papst MH, Rosenberg D, Rutherford R, Sareault JE (2008) Beaufort Sea Large Ocean Management Area: Ecosystem Overview and Assessment Report. Can Tech Rep Fish Aquat Sci 2780: ii-ix + 188 p

Connelly TL, Deibel D, Parrish CC (2014) Trophic interactions in the benthic boundary layer of the Beaufort Sea shelf, Arctic Ocean: Combining bulk stable isotope and fatty acid signatures. Prog Oceanogr 120:79-92. doi: 10.1016/j.pocean.2013.07.032

Craig H (1957) Isotopic standards for carbon and oxygen and correction factors for mass-spectrometric analysis of carbon dioxide. Geochim Cosmochim Acta 12:133-149. doi: 10.1016/00167037(57)90024-8

Craig P, Griffiths B, Haldorson L, McElderry H (1982) Ecological studies of Arctic Cod (Boreogadus saida) in Beaufort Sea coastal waters, Alaska. Can Bull Fish Aquat Sci 39:395-406. doi: $10.1139 / \mathrm{f} 82-057$

Crawford RE, Jorgenson JK (1996) Quantitative Studies of Arctic cod (Boreogadus saida) Schools: important energy stores in the Arctic food web. Arctic 49: 181-193

Crawford RE, Vagle S, Carmack EC (2012) Water mass and bathymetric characteristics of polar cod habitat along continental shelf and slope of the Beaufort and Chukchi seas. Polar Biol 35:179-190

Divine LM, Iken K, Bluhm BA (2015) Regional benthic food web structure on the Alaska Beaufort Sea shelf. Mar Ecol Prog Ser 531:15-32

Dunton KH, Saupe SM, Golikov an N, et al (1989) Trophic relationships and isotopic gradients among arctic and subarctic marine fauna. Mar Ecol Prog Ser 56:89-97. doi: 10.3354/meps056089

Dunton KH, Schonber SV (2012) Food Web Structure of the Alaskan Nearshore Shelf and Estuarine Lagoons of the Beaufort Sea. Fisheries and Coastal 35:416-435 
Dunton KH, Weingartner T, Carmack EC (2006) The nearshore western Beaufort Sea ecosystem: Circulation and importance of terrestrial carbon in arctic coastal food webs. Prog Oceanogr $71: 362-378$

El-Sabaawi R, Dower JF, Kainz M, Mazumder A (2009) Characterizing dietary variability and trophic positions of coastal calanoid copepods: Insight from stable isotopes and fatty acids. Mar Biol 156:225-237. doi: 10.1007/s00227-008-1073-1

Falk-Petersen S, Dahl TM, Scott CL, Sargent JR, Gulliksen B, Kwasniewski S, Hop H, Millar RM (2002) Lipid biomarkers and trophic linkages between ctenophores and copepods in Svalbard waters. Mar Ecol Prog Ser 227: 187-194. doi:10.3354/meps227187

Folch J, Lees M, Stanley GHS (1957) A simple method for the isolation and purification of total lipids from animal tissues. J Biol Chem 226:497-509. doi: 10.1007/s10858-011-9570-9

Fry B (2006) Stable Isotope Ecology. Springer New York, Baton Rouge, Louisiana

Gallaway BJ, Norcross BL (2011) A synthesis of diversity, distribution, abundance, age, size and diet of fishes in the lease sale 193 area of the Northeastern Chukchi Sea. Final Report. Conoco Phillips Alaska Inc, Shell Exploration \& Production Company and Statoil USA E \& P Inc

Geoffroy M, Majewski A, LeBlanc M et al (2016) Vertical segregation of age-0 and age-1+ polar cod (Boreogadus saida) over the annual cycle in the Canadian Beaufort Sea. Polar Biol 39:1023-1037. doi: $10.1007 / \mathrm{s} 00300-015-1811-\mathrm{z}$

Giraldo C, Stasko A, Choy ES et al (2016) Trophic variability of Arctic fishes in the Canadian Beaufort Sea: a fatty acids and stable isotopes approach. Polar Biol 39:1267-1282. doi: 10.1007/s00300-015$1851-4$ 
Griffiths WB, Fechhelm RG, Gallaway BJ, Martin LR, Wilson WJ (1998) Abundance of selected fish species in relation to temperature and salinity patterns in the Sagavanirktok Delta, Alaska, following construction of the Endicott Causeway. Arctic 51: 94-104

Graeve M, Kattner G, Piepenburg D (1997) Lipids in arctic benthos: Does the fatty acid and alcohol composition reflect feeding and trophic interactions? Polar Biol 18:53-61. doi: $10.1007 / \mathrm{s} 003000050158$

Gray BP, Norcross BL, Blanchard AL et al (2016) Variability in the summer diets of juvenile polar cod (Boreogadus saida) in the northeastern Chukchi and western Beaufort Seas. Polar Biol 39:10691080. doi: 10.1007/s00300-015-1796-7

Hansen JH, Hedeholm RB, Snksen K et al (2012) Spatial variability of carbon $\left(\delta^{13} \mathrm{C}\right)$ and nitrogen $\left(\delta^{15} \mathrm{~N}\right)$ stable isotope ratios in an Arctic marine food web. Mar Ecol Prog Ser 467:47-59. doi: $10.3354 /$ meps09945

Hobson KA, Welch HE (1992) Determination of trophic relationships within a high Arctic marine food web using $\delta^{13} \mathrm{C}$ and $\delta^{15} \mathrm{~N}$ analysis. Mar Ecol Prog Ser 84: 9-18

Hobson KA, Ambrose WG, Renaud, PE (1995) Sources of primary production, benthic-pelagic coupling, and trophic relationships within the Northeast Water Polynya: insights from $\delta^{13} \mathrm{C}$ and $\delta^{15} \mathrm{~N}$ analysis. Mar Ecol Prog Ser 128: 1-10

Hobson et al. 2002 A stable isotope $\left(\delta^{13} \mathrm{C}, \delta{ }^{15} \mathrm{~N}\right)$ model for the North Water food web: implications for evaluating trophodynamics and the flow of energy and contaminants. Deep Sea Res II 49: 51315150

Hussey NE, MacNeil MA, McMeans BC, Olin JA, Dudley SFJ, Cliff G, Wintner SP, Fennessey ST, Fisk AT (2014) Rescaling the trophic structure of marine food webs. Ecol Lett 17: 239-250 
Iken K, Bluhm BA, Gradinger R (2005) Food web structure in the high Arctic Canada Basin: evidence from $\delta 13 \mathrm{C}$ and $\delta 15 \mathrm{~N}$ analysis. Polar Biol 28: 238-249

Iverson SJ, Frost KJ, Lang SLC (2002) Fat content and fatty acid composition of forage fish and invertebrates in Prince William Sound, Alaska: factors contributing to among and within species variability. Mar Ecol Prog Ser 241: 161-181

Iverson SJ, Field C, Bowen WD, Blanchard W (2004) Quantitative Fatty Acid Signature Analysis: A new method of investigating predator diets. Ecol Monogr 74: 211-235

Iverson SJ, Springer AM, Kitaysky AS (2007) Seabirds as indicators of food web structure and ecosystem variability: qualitative and quantitative diet analyses using fatty acids. Mar Ecol Prog Ser 352: 235244. doi: $10.3354 /$ meps07073

Jackson AL, Inger R, Parnell AC, Bearhop S (2011) Comparing isotopic niche widths among and within communities: SIBER - Stable Isotope Bayesian Ellipses in R. J Anim Ecol 80:595-602. doi: 10.1111/j.1365-2656.2011.01806.x

Johnson, JD (1995) Description and Comparison of Two Populations of Saffron Cod (Eleginus gracilis) from Western Canadian Arctic Coastal Waters. MSc thesis, Univ Manitoba Winnipeg Manitoba Canada, pp133

Johnson SW, Thedinga JF, Neff AD (2009) Invasion by saffron cod Eleginus gracilis into nearshore habitats of Prince William Sound, Alaska, USA. Mar Ecol Prog Ser 389:203-212. doi: $10.3354 /$ meps08226

Kelly JR, Scheibling RE (2012) Fatty acids as dietary tracers in benthic food webs. Mar Ecol Prog Ser 446:1-22 
Knickle DC, Rose GA (2014) Dietary niche partitioning in sympatric gadid species in coastal

Newfoundland : evidence from stomachs and C-N isotopes. Environ Biol Fishes 343-355. doi:

10.1007/s10641-013-0156-0

Lacho G (1991) Stomach content analyses of fishes from Tuktoyaktuk Harbour, N.W.T., 1981. Can Data Rep Fish Aquat Sci 853: iv + 10 p

Layman CA, Arrington DA, Montaňa CG, Post DM (2007) Can stable isotope ratios provide for community-wide measures of trophic structure. Ecology 88: 42-48

Legezynska J, Kedra M, Walkusz W (2014) Identifying trophic relationships within the high Arctic benthic community: how much can fatty acids tell? Mar Biol 161:821-836. doi: 10.1007/s00227-013 $2380-8$

Loseto LL, Stern GA, Connelly TL, Deibel D, Gemmill B, Prokopowicz A, Fortier L, Ferguson SH (2009) Summer diet of beluga whales inferred by fatty acid analysis of the eastern Beaufort Sea food web. J Exper Mar Biol Ecol 374: 12-18

Lynn, BR (2016) Sex- and age-dependent differences and habitat influences on demersal Arctic cod (Boreogadus saida, Lepechin 1774) diet and energy allocation in the Canadian Beaufort Sea. MSc thesis, Univ Manitoba Winnipeg Manitoba Canada 200p

Majewski AR, Atchison SP, MacPhee SA, Eert J, Niemi A, de Montety L, Michel C, Reist, JD (2017) Marine fish community structure and habitat associations on the Canadian Beaufort shelf and slope. Deep Res 121:169-182

Majewski AR, Reist JD, Sareault JE (2006) Fish catch data from offshore sites in the Mackenzie River estuary and Beaufort Sea during the open water season, August 2004, aboard the CCGS Nahidik. Can MS Rep Fish Aquat Sci 2771: vi + 37 p 
Majewski AR, Suchy KD, Atchison SP, Henry J, MacPhee SA, Walkusz W, Eert J, Dempsey M, Niemi A, de Montety L, Geoffroy M, Giraldo C, Michel C, Archambault P, Williams WJ, Fortier L, Reist, JD (2016a) Uniqueness of Fishes and Habitat Utilization in Oil \& Gas Lease Blocks Relative to NonLease Areas in the Canadian Beaufort Sea. Environmental Studies Revolving Funds. Rep Ser No 203, Ottawa. xi $+90 p$

Majewski AR, Walkusz W, Lynn BR, Atchison S, Eert J, Reist JD (2016b) Distribution and diet of demersal Arctic Cod, Boreogadus saida, in relation to habitat characteristics in the Canadian Beaufort Sea. Polar Biol 39:1087-1098

Mariotti A (1983) Atmospheric nitrogen is a reliable standard for natural $15 \mathrm{~N}$ abundance measurements. Nature 303:685-687

Matley JK, Fisk AT, Dick TA (2013) The foraging ecology of Arctic cod (Boreogadus saida) during open water (July-August) in Allen Bay, Arctic Canada. Mar Biol 160:2993-3004. doi: 10.1007/s00227$013-2289-2$

Mecklenburg CW, Rask Møller P, Steinke D (2011) Biodiversity of arctic marine fishes: taxonomy and zoogeography. Mar Biodiv 41:109-140. doi 10.1007/s12526-010-0070-z

Mintenbeck K, Brey T, Jacob U, Knust R, Struck U (2008) How to account for the lipid effect on carbon stable-isotope ratio (delta C-13): sample treatment effects and model bias. J. Fish Biol 72: 815-830

Morin B, Hudon C, Whoriskey F (1991) Seasonal distribution, abundance, and life-history traits of Greenland cod, Gadus ogac, at Wemindji, easternJames Bay. Can J Zool 69:3061-3070

Morrison WR, Smith LM (1964) Preparation of Fatty Acid Methyl Esters and Dimethylacetals From Lipids With Boron Fluoride--Methanol. J Lipid Res 5:600-608 
Newsome SD, del Rio CM, Bearhop S, Phillips DL (2007) A niche for isotopic ecology. Front Ecol Environ 5: 429-436. doi:10.1890/060150.01

Nielsen JR, Andersen M (2001) Feeding Habits and Density Pattern of Greenland Cod, Gadus ogac (Richardson, 1836), at West Greenland Compared to Those of the Coexisting Atlantic Cod, Gadus morhua L. J Northw Atlant Fish Sci 29: 1-22

Parker-Stetter SL, Horne JK, Weingartner TJ (2011) Distribution of polar cod and age-0 fish in the U.S. Beaufort Sea. Polar Biol 34: 1543-1557

Post DM (2002) Using stable isotopes to estimate trophic position: models, methods and assumptions. Ecology 83: 703-718

Rand KM, Logerwll EA (2011) The first demersal trawl survey of benthic fish and invertebrates in the Beaufort Sea since the late 1970s. Polar Biol 34:475-488

Saupe SM, Schell DM, Griffiths WB (1989) Carbon-isotope ratio gradients in western arctic zooplankton. Mar Biol 103:427-432. doi: 10.1007/BF00399574

Schell DM, Saupe SM, Haubenstock N (1989) Bowhead whale (Balaena mysticetus) growth and feeding as estimated by d13C techniques. Mar Biol 103:433-443. doi: 10.1007/BF00399575

Stasko AD, Swanson H, Majewski A, Atchinson S, Reist J, Power M (2016) Influences of depth and pelagic subsidies on the size-based trophic structure of Beaufort Sea fish communities. Mar Ecol Prog Ser 549: 153-166

Stein R, Macdonald RW (2004) The organic carbon cycle in the Arctic Ocean. New York: Springer 
Swanson HK, Kidd KA, Reist JD (2010) Effects of partially anadromous Arctic charr (Salvelinus alpinus) populations on ecology of coastal Arctic lakes. Ecosystems 13:261-274. doi: 10.1007/s10021-0109316-7

Swanson HK, Lysy M, Power M, et al (2015) A new probabilistic method for quantifying n-dimensional ecological niches and niche overlap. Ecology 96:318-324. doi: 10.1890/14-0235.1

Tocher DR (2003) Metabolism and Functions of Lipids and Fatty Acids in Teleost Fish. Rev Fish Sci $11: 107-184$

Tocher DR (2010) Fatty acid requirements in ontogeny of marine and freshwater fish. Aquac Res 41:717732. doi: $10.1111 / \mathrm{j} .1365-2109.2008 .02150 . \mathrm{x}$

Tucker S, Bowen WD, Iverson SJ (2008) Convergence of diet estimates derived from fatty acids and stable isotopes within individual grey seals. Mar Ecol Prog Ser 354: 267-276

Turner TF, Collyer ML, Krabbenhoft TJ (2010) A general hypothesis-testing framework for stable isotope ratios in ecological studies. Ecology 91:2227-2233. doi: 10.1890/09-1454.1

Von Biela et al (2013) Terrestrial and marine trophic pathways support young-of-year growth in a nearshore Arctic fish. Polar Biol 36: 137-146 . doi: 10.1007/s00300-012-1244-x

Wassman P, Duarte CM, Agustì S, Sejr, MK (2011) Footprints of climate change in the Arctic marine ecosystem. Global Change Biol 17: 1235-1249. doi: 10.1111/j.1365-2486.2010.02311.x

Walkusz W, Majewski A, Reist JD (2013) Distribution and diet of the bottom dwelling Arctic cod in the Canadian Beaufort Sea. J Mar Syst 125: 65-75 
Welch HE, Bergmann MA, Siferd TD, Martin KA, Curtis MF, Crawford RE, Conover RJ, Hop H (1992)

Energy Flow through the Marine Ecosystem of the Lancaster Sound Region, Arctic Canada. Arctic 45: $343-357$

Welch HE, Crawford RE, Hop H (1993) Occurrence of Arctic cod (Boreogadus saida) schools and their vulnerability to predation in the Canadian High Arctic. Arctic 46: 331-339 


\section{Figure Captions}

Fig. 1 Map of the locations that polar cod, saffron cod and Greenland cod were sampled from in 2012. Shingle Point represents the coastal-estuarine habitat where saffron cod were collected. Ulukhaktok and Sachs Harbour represent the coastal-marine habitats where Greenland cod were collected. The three offshore habitats: lower-slope, upper-slope, and shelf represent the marine habitats where polar cod were collected.

Fig. 2 Stable isotope composition $\left(\delta^{13} \mathrm{C}\right.$ and $\left.\delta^{15} \mathrm{~N}\right)$ of polar cod, Greenland cod, and saffron cod. Polar cod (circles), Greenland cod (triangles) and saffron cod (cross). The standard ellipse areas represent $40 \%$ of each niche region.

Fig. 3 Correspondence analysis for the FA signatures of polar cod, saffron cod, and Greenland cod. Ellipses representing $95 \%$ confidence intervals were included to identify overlap.

Fig. 4a Isotopic ellipses of Greenland cod captured from two locations: Sachs Harbour, and Ulukhaktok. The isotopic signatures $\left(\delta^{13} \mathrm{C}\right.$ and $\left.\delta^{15} \mathrm{~N}\right)$ were used as variables and indicate the niche breadth of each species. The standard ellipse areas represent $40 \%$ of each niche region.

Fig. 4b Discriminant analysis of the FA composition for Greenland cod collected at Ulukhaktok and Sachs Harbour. The first and only discriminant function accounts for $100 \%$ of the variance in fatty acid composition among sampling sites. FA on the negative side characterized Greenland cod individuals collected from Sachs Harbour, and on the positive, Greenland cod collected from Ulukhaktok.

Fig. 5 Isotopic ellipse of polar cod captured from three locations: shelf, upper-slope, and lower-slope. The isotopic signatures $\left(\delta^{13} \mathrm{C}\right.$ and $\left.\delta^{15} \mathrm{~N}\right)$ were used as variables and indicate for niche breadth of each species. The standard ellipse areas represent $40 \%$ of each niche region. 
Fig. 6 Discriminant analysis of polar cod captured at 3 sampling sites (depth zones) in the Canadian Arctic where a) the first discriminant function accounts for $53.78 \%$ of the variance in fatty acid composition among sampling sites, and b) the second discriminant function accounts for $46.22 \%$. 
Figures

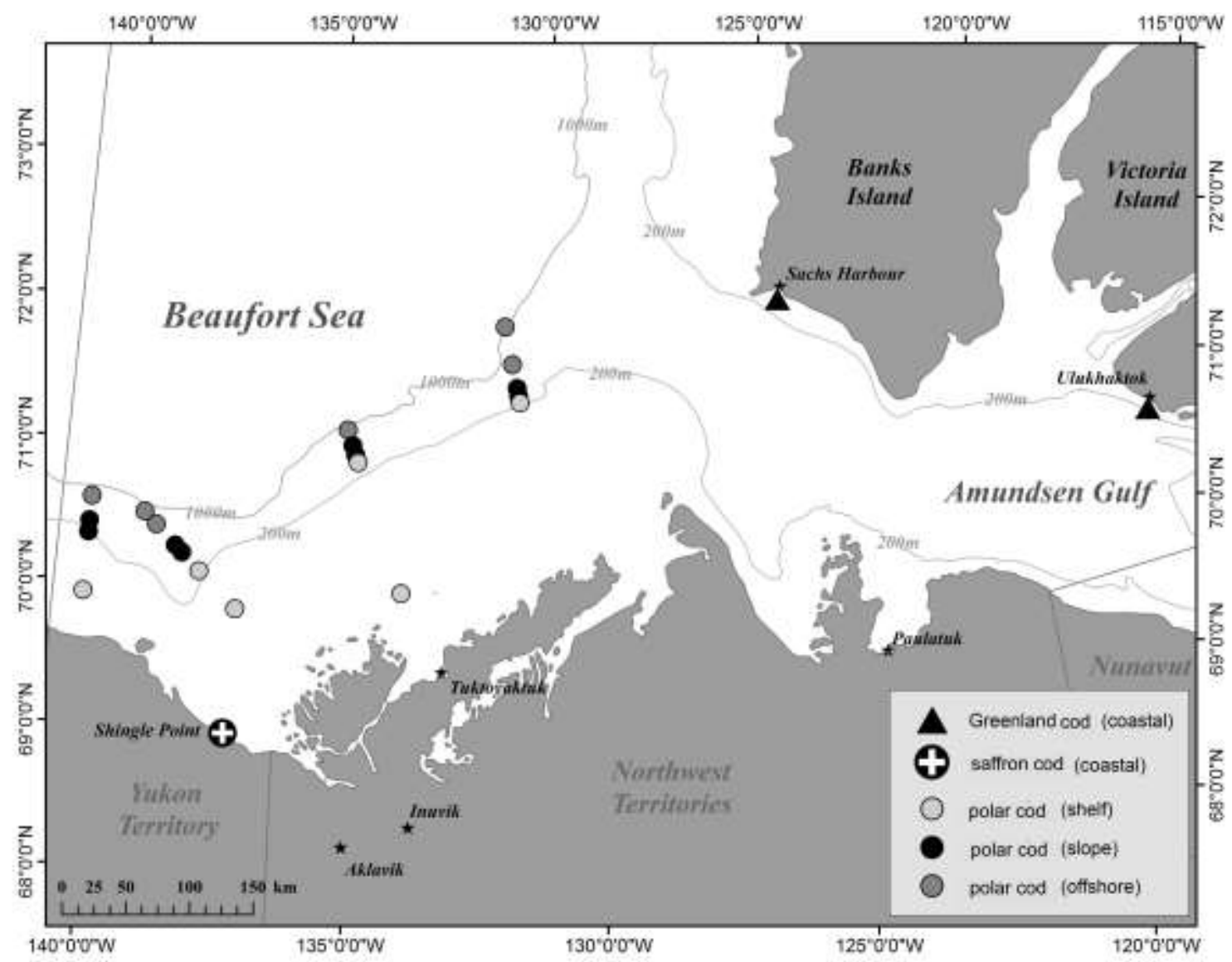

Fig. 1 


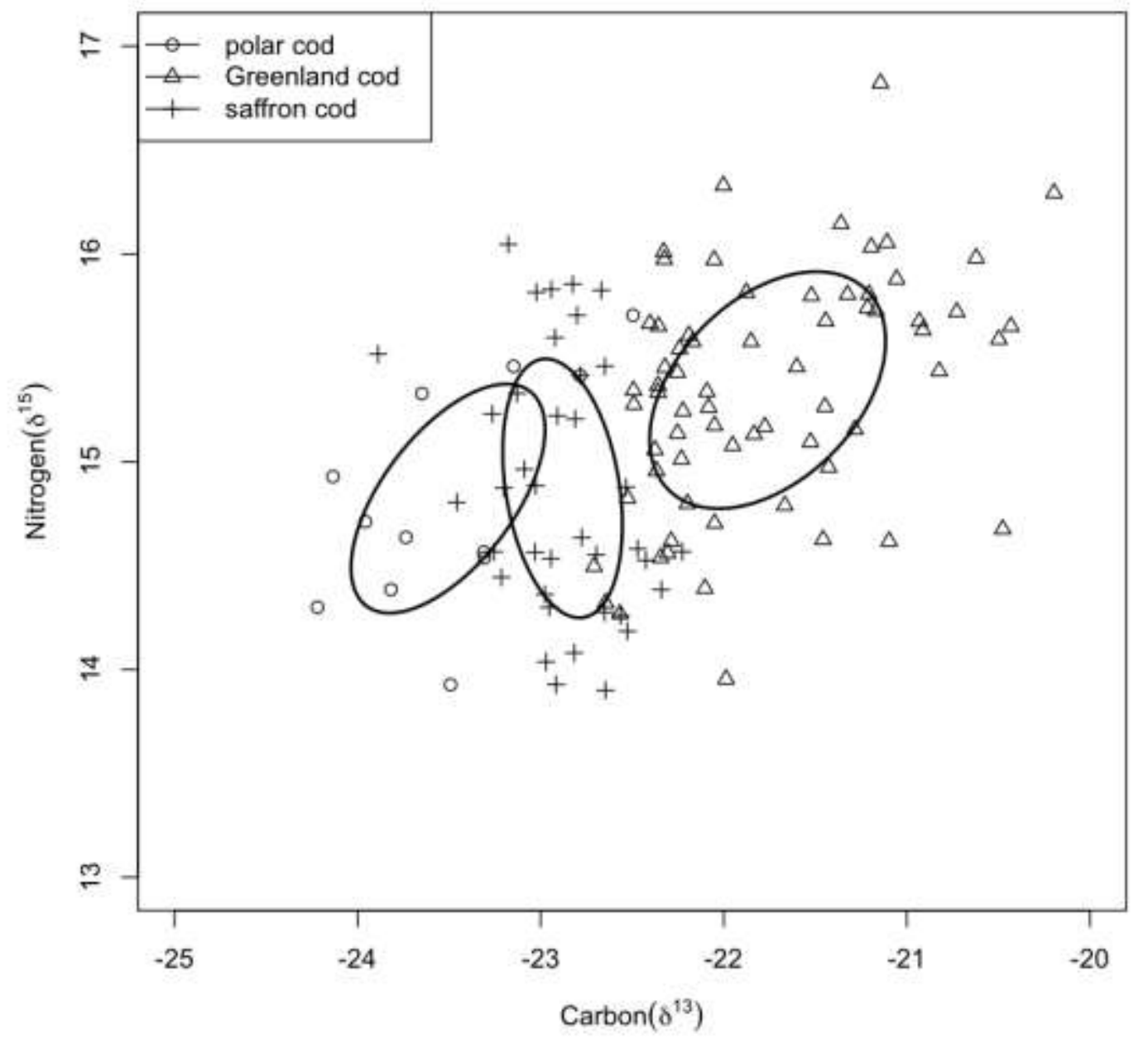

Fig. 2 


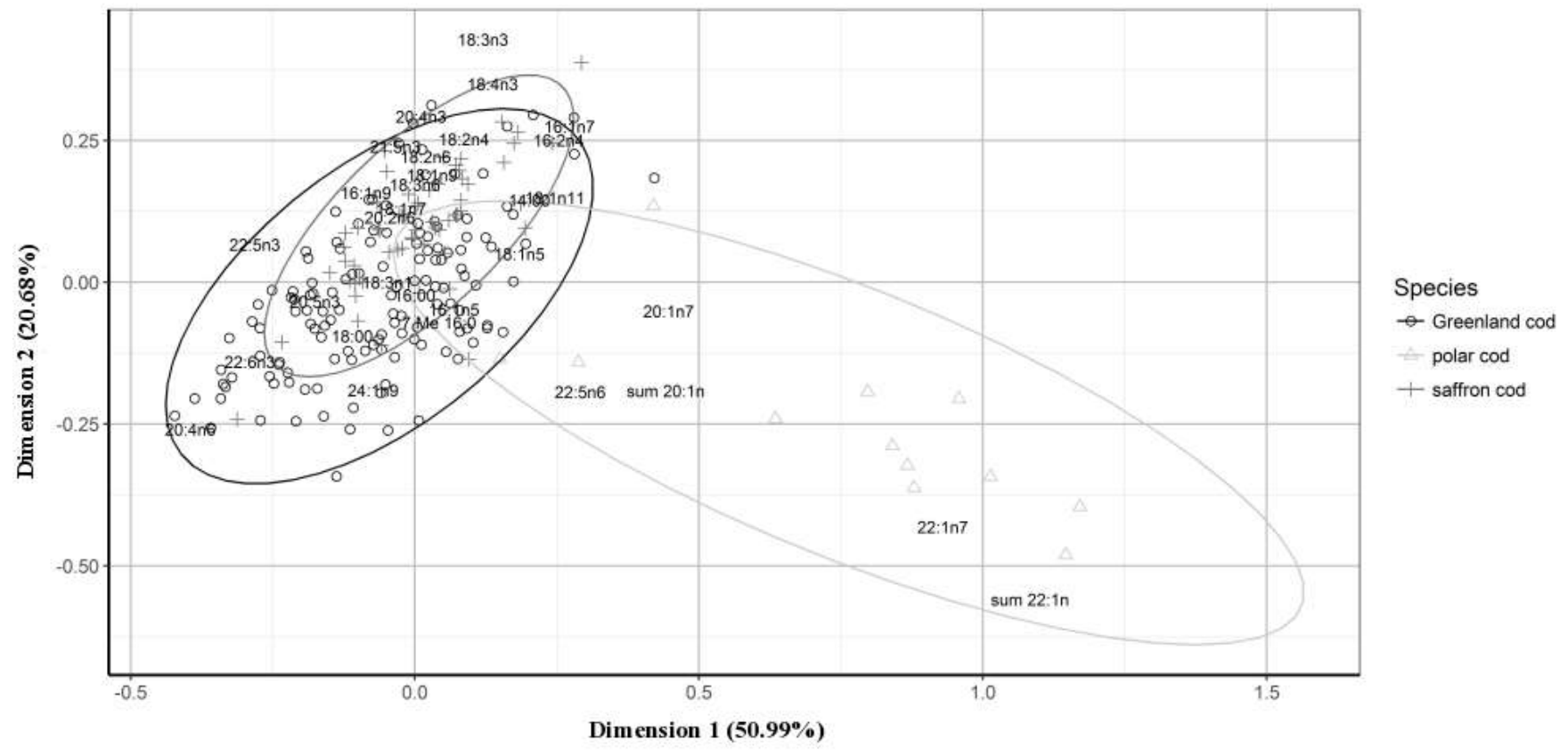

Fig. 3 


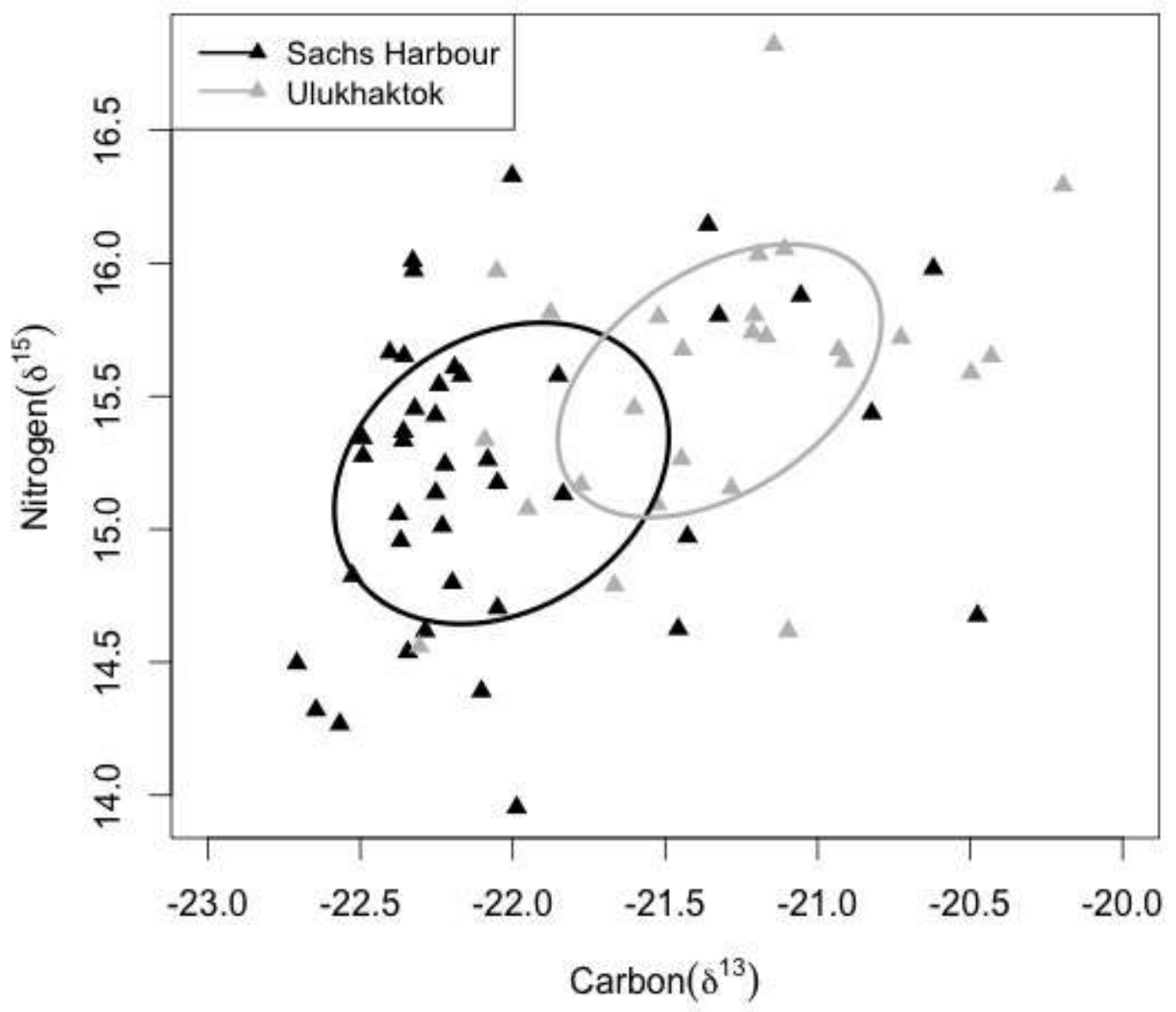

Fig. 4a 


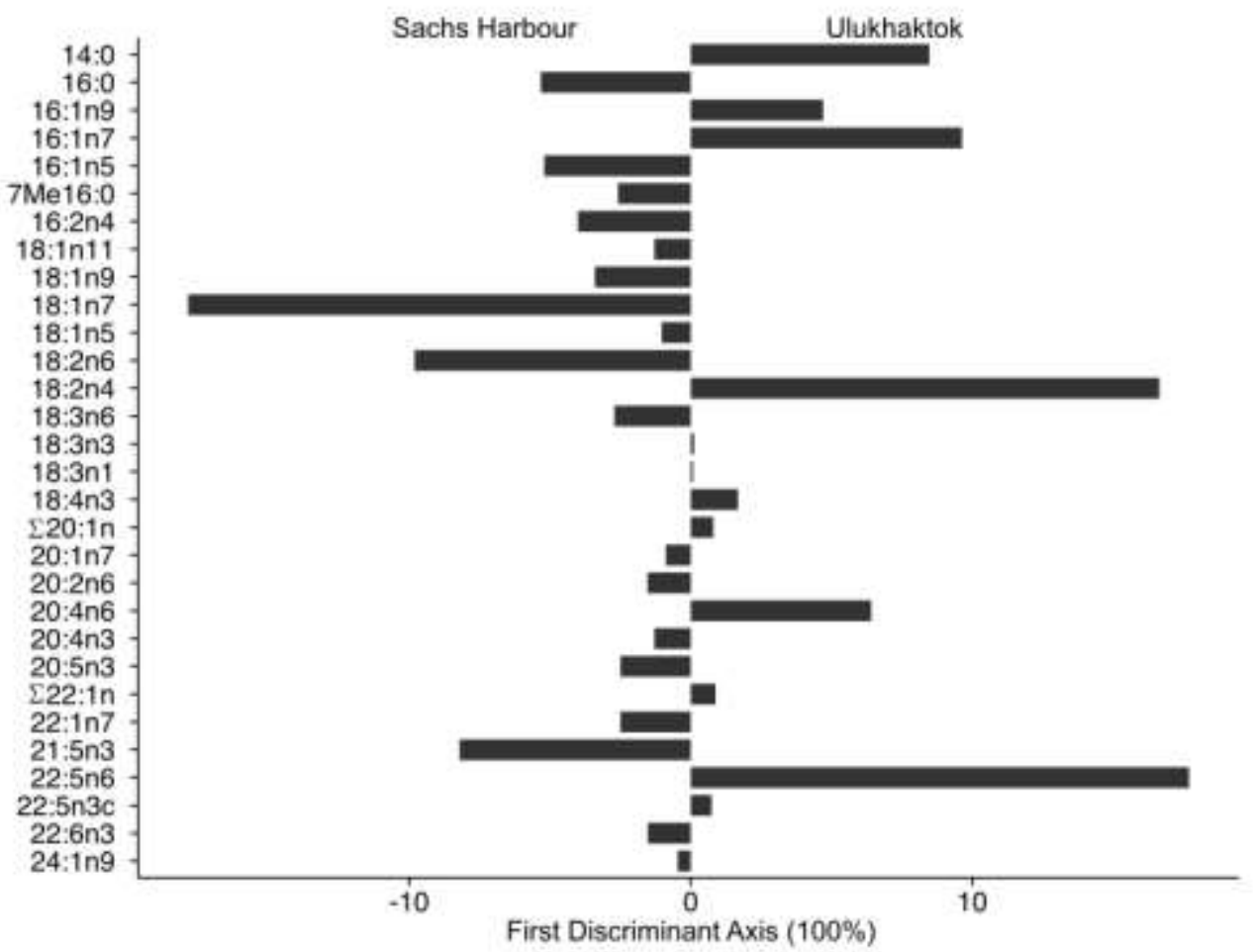

Fig. 4b 


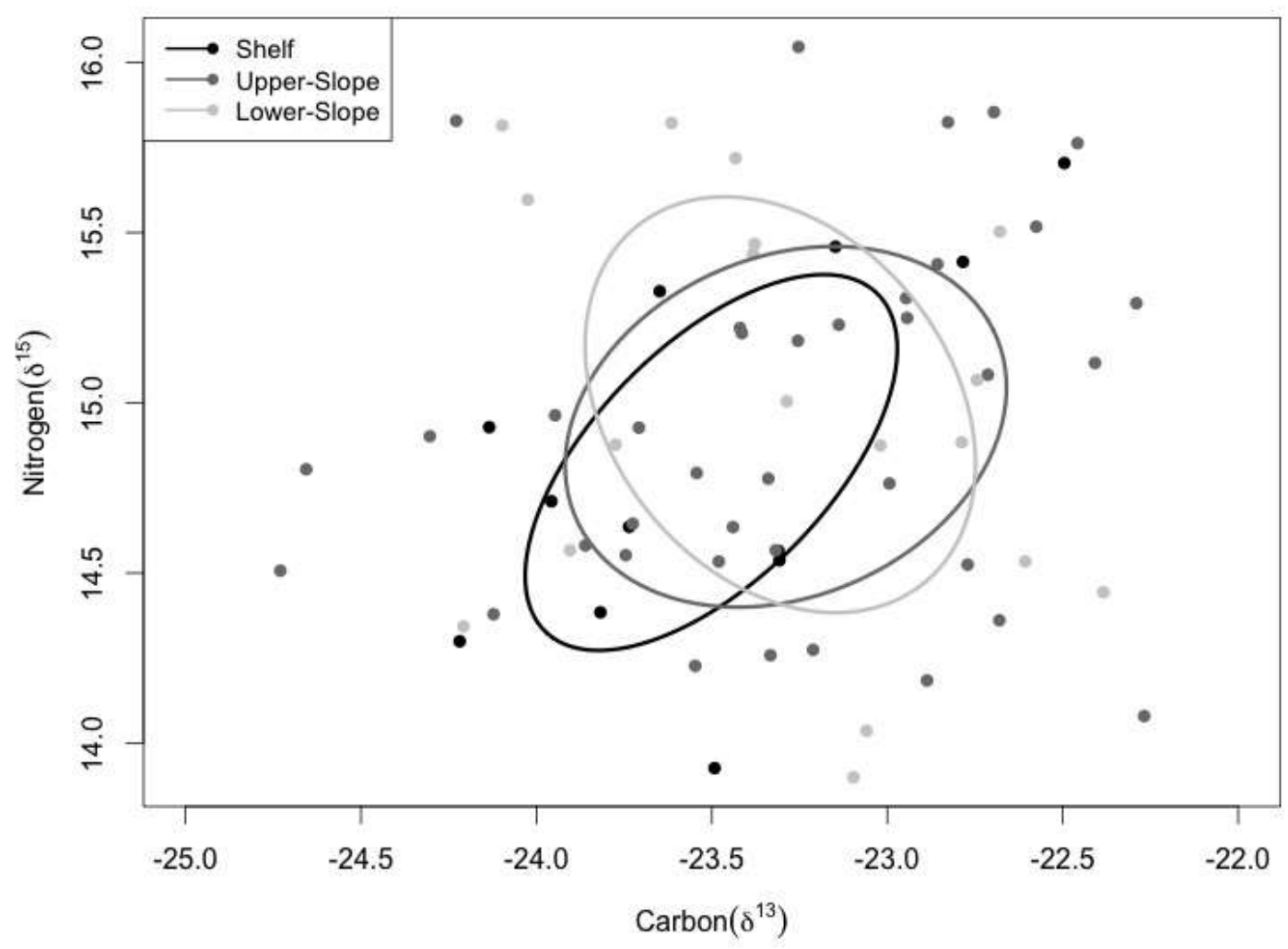

Fig. 5 


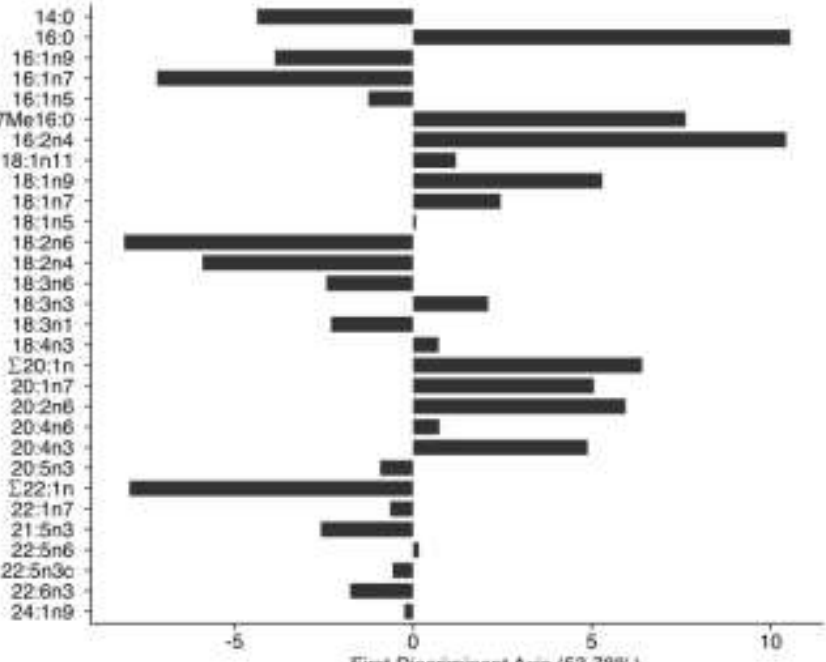

a)

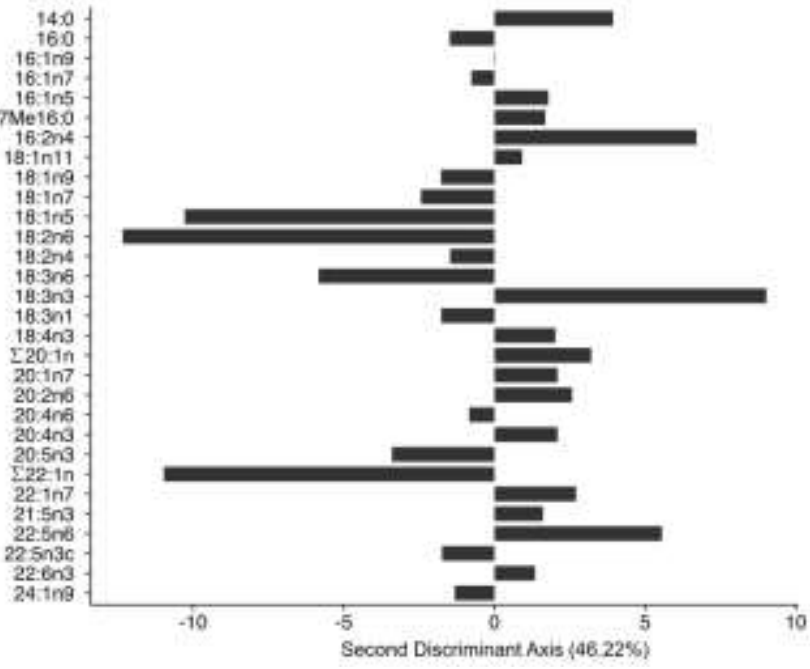

b)

Fig. 6 


\section{Tables}

Table 1 Biological data and stable isotopes signatures $\left(\delta^{13} \mathrm{C}, \delta^{15} \mathrm{~N}\right.$ in \%o) of the three species of cod. Values are reported as $\overline{\boldsymbol{x}} \pm \mathrm{SE}$. The ranges in $\delta^{13} \mathrm{C}\left(\delta^{13} \mathrm{CR}\right)$ and $\delta^{15} \mathrm{~N}$ $\left(\delta^{15} \mathrm{NR}\right)$ values were reported. Polar cod and saffron cod data were subsamples from the previous studies Lynn (2016), and Brewster et al. (2016), respectively.

\begin{tabular}{|c|c|c|c|c|c|c|c|}
\hline Species & Location $(n)$ & $\begin{array}{l}\text { Fork Length (mm) } \\
(\bar{x} \pm \mathrm{SE})\end{array}$ & $\begin{array}{l}\text { \% Lipid } \\
(\bar{x} \pm \mathrm{SE})\end{array}$ & $\delta^{13} \mathrm{C}(\overline{\boldsymbol{x}} \pm \mathrm{SE})$ & $\delta^{13} \mathrm{CR}$ & $\delta^{15} \mathrm{~N}(\bar{x} \pm \mathrm{SE})$ & $\delta^{15} \mathrm{NR}$ \\
\hline $\begin{array}{l}\text { Polar cod } \\
\text { ( Boreogadus saida) }\end{array}$ & 70 & $128.55 \pm 3.47$ & $20.34 \pm 1.29$ & $-23.33 \pm 0.07$ & 2.46 & $14.93 \pm 0.07$ & 2.15 \\
\hline Shelf & 12 & $108.20 \pm 6.83$ & $21.52 \pm 1.87$ & $-23.50 \pm 0.15$ & 1.72 & $14.82 \pm 0.16$ & 1.78 \\
\hline Upper-slope & 40 & $130.65 \pm 3.71$ & $20.07 \pm 2.16$ & $-23.29 \pm 0.10$ & 2.46 & $14.93 \pm 0.08$ & 1.97 \\
\hline Lower-slope & 18 & $137.69 \pm 8.60$ & $20.14 \pm 1.26$ & $-23.30 \pm 0.13$ & 1.82 & $14.99 \pm 0.14$ & 1.92 \\
\hline $\begin{array}{l}\text { Greenland cod } \\
\text { (Gadus ogac) }\end{array}$ & 66 & $401.25 \pm 5.48$ & $12.25 \pm 0.56$ & $-21.76 \pm 0.08$ & 2.51 & $15.34 \pm 0.07$ & 2.86 \\
\hline Sachs Harbour & 41 & $379.54 \pm 4.38$ & $11.11 \pm 0.60$ & $-21.91 \pm 0.09$ & 2.42 & $14.93 \pm 0.09$ & 2.98 \\
\hline Ulukhaktok & 25 & $435.50 \pm 8.90$ & $11.00 \pm 1.02$ & $-21.15 \pm 0.13$ & 2.13 & $16.00 \pm 0.13$ & 2.85 \\
\hline $\begin{array}{l}\text { Saffron cod } \\
\text { (Eleginus gracilis) }\end{array}$ & 38 & $436.53 \pm 3.51$ & $13.40 \pm 0.82$ & $-22.88 \pm 0.05$ & 1.66 & $15.18 \pm 0.08$ & 2.57 \\
\hline
\end{tabular}


Table 2 Probabilities of niche overlap were calculated and refer to the probability of Species A niche being found in the niche of Species B. Confidence intervals were calculated to show the minimum and maximum percent of overlap.

\begin{tabular}{|c|c|c|c|}
\hline Species B & Species A & $\begin{array}{l}\text { Probability of } \\
\text { Overlap }\end{array}$ & $\begin{array}{l}\text { Confidence Intervals (\%) } \\
\text { [minimum, maximum] }\end{array}$ \\
\hline \multicolumn{4}{|l|}{ Among Species } \\
\hline \multirow[t]{2}{*}{ Polar cod } & Greenland cod & $0.16 \%$ & {$[0.00,0.81]$} \\
\hline & Saffron cod & $13.36 \%$ & {$[1.80,36.93]$} \\
\hline \multirow[t]{2}{*}{ Greenland cod } & Polar cod & $0.28 \%$ & {$[0.00,1.96]$} \\
\hline & Saffron cod & $1.06 \%$ & {$[0.07,4.19]$} \\
\hline \multirow[t]{2}{*}{ Saffron cod } & Polar cod & $14.61 \%$ & {$[4.80,28.16]$} \\
\hline & Greenland cod & $1.41 \%$ & {$[0.32,3.51]$} \\
\hline \multicolumn{4}{|l|}{ Within Species: Polar cod } \\
\hline \multirow[t]{2}{*}{ Polar cod (shelf) } & Polar cod (upper-slope) & $25.17 \%$ & {$[14.69,41.00]$} \\
\hline & Polar cod (lower-slope) & $22.73 \%$ & {$[10.56,38.59]$} \\
\hline \multirow[t]{2}{*}{ Polar cod (upper-slope) } & Polar cod (shelf) & $44.61 \%$ & {$[25.58,65.91]$} \\
\hline & Polar cod (lower-slope) & $36.84 \%$ & {$[23.22,51.39]$} \\
\hline \multirow[t]{2}{*}{ Polar cod (lower-slope) } & Polar cod (shelf) & $38.39 \%$ & {$[19.89,60.91]$} \\
\hline & Polar cod (upper-slope) & $35.36 \%$ & {$[21.63,51.04]$} \\
\hline \multicolumn{4}{|l|}{ Within Species: Greenland cod } \\
\hline Greenland cod (Ulukhaktok) & Greenland cod (Sachs Harbour) & $8.08 \%$ & {$[2.57,16.67]$} \\
\hline Greenland cod (Sachs Harbour) & Greenland cod (Ulukhaktok) & $14.54 \%$ & {$[5.08,27.25]$} \\
\hline
\end{tabular}


Table 3 Percent (\%) total fatty acid (FA) content for the three cod species indicated as $\overline{\boldsymbol{x}} \pm$ SE. Only main FA (> 1\%) are indicated. The FA signature $\Sigma$ C20:1 encompass: 20:1n9 and 20:1n11; $\Sigma$ C22:1 encompass: 22:1n 9 and 22:1n11.

\begin{tabular}{|c|c|c|c|}
\hline & Polar cod & Greenland cod & Saffron cod \\
\hline \multicolumn{4}{|c|}{ Saturated FA (\%) } \\
\hline $14: 0$ & $2.93 \pm 0.11$ & $2.17 \pm 0.05$ & $2.22 \pm 0.08$ \\
\hline $16: 0$ & $16.39 \pm 0.36$ & $15.01 \pm 0.17$ & $14.08 \pm 0.17$ \\
\hline $18: 0$ & $2.80 \pm 0.09$ & $3.40 \pm 0.05$ & $2.27 \pm 0.07$ \\
\hline subtotal & $22.12 \pm 0.56$ & $20.58 \pm 0.27$ & $18.57 \pm 0.32$ \\
\hline \multicolumn{4}{|c|}{ Monounsaturated FA (\%) } \\
\hline $16: 1 \mathrm{n} 9$ & $0.22 \pm 0.01$ & $0.36 \pm 0.01$ & $0.52 \pm 0.02$ \\
\hline $16: 1 \mathrm{n} 7$ & $14.31 \pm 0.46$ & $10.17 \pm 0.31$ & $12.47 \pm 0.36$ \\
\hline $16: 1 \mathrm{n} 5$ & $0.41 \pm 0.01$ & $0.30 \pm 0.01$ & $0.25 \pm 0.01$ \\
\hline $18: \ln 11$ & $1.74 \pm 0.06$ & $1.01 \pm 0.04$ & $1.59 \pm 0.06$ \\
\hline $18: 1 \mathrm{n} 9$ & $8.59 \pm 0.23$ & $8.53 \pm 0.16$ & $11.07 \pm 0.19$ \\
\hline $18: 1 n 7$ & $4.79 \pm 0.11$ & $6.14 \pm 0.08$ & $6.41 \pm 0.12$ \\
\hline $18: 1 \mathrm{n} 5$ & $0.72 \pm 0.02$ & $0.47 \pm 0.01$ & $0.47 \pm 0.01$ \\
\hline$\Sigma \mathrm{C} 20: 1$ & $9.52 \pm 0.35$ & $4.55 \pm 0.15$ & $4.21 \pm 0.13$ \\
\hline $20: 1 \mathrm{n} 7$ & $1.45 \pm 0.17$ & $0.73 \pm 0.03$ & $0.72 \pm 0.04$ \\
\hline$\sum \mathrm{C} 22: 1$ & $10.21 \pm 0.53$ & $2.11 \pm 0.10$ & $2.12 \pm 0.13$ \\
\hline $22: 1 \mathrm{n} 7$ & $0.55 \pm 0.04$ & $0.14 \pm 0.01$ & $0.13 \pm 0.01$ \\
\hline $24: 1 \mathrm{n} 9$ & $0.80 \pm 0.03$ & $0.63 \pm 0.02$ & $0.60 \pm 0.06$ \\
\hline subtotal & $53.31 \pm 2.02$ & $35.14 \pm 0.93$ & $40.56 \pm 1.14$ \\
\hline \multicolumn{4}{|c|}{ Polyunsaturated FA (\%) } \\
\hline $16: 2 \mathrm{n} 4$ & $0.37 \pm 0.01$ & $0.27 \pm 0.01$ & $0.31 \pm 0.01$ \\
\hline $18: 2 \mathrm{n} 6$ & $0.62 \pm 0.01$ & $0.82 \pm 0.04$ & $0.85 \pm 0.02$ \\
\hline $18: 2 n 4$ & $0.11 \pm 0.00$ & $0.12 \pm 0.00$ & $0.17 \pm 0.00$ \\
\hline $18: 3 n 6$ & $0.10 \pm 0.00$ & $0.22 \pm 0.01$ & $0.10 \pm 0.00$ \\
\hline $18: 3 n 3$ & $0.26 \pm 0.01$ & $0.33 \pm 0.02$ & $0.46 \pm 0.02$ \\
\hline $18: 3 \mathrm{n} 1$ & $0.12 \pm 0.01$ & $0.11 \pm 0.00$ & $0.09 \pm 0.00$ \\
\hline $18: 4 \mathrm{n} 3$ & $0.37 \pm 0.02$ & $0.50 \pm 0.02$ & $0.50 \pm 0.03$ \\
\hline $20: 2 \mathrm{n} 6$ & $0.18 \pm 0.00$ & $0.30 \pm 0.01$ & $0.30 \pm 0.01$ \\
\hline $20: 4 n 6$ & $0.57 \pm 0.03$ & $2.47 \pm 0.09$ & $1.53 \pm 0.06$ \\
\hline $20: 4 n 3$ & $0.24 \pm 0.00$ & $0.32 \pm 0.01$ & $0.62 \pm 0.02$ \\
\hline $20: 5 n 3$ & $8.16 \pm 0.22$ & $14.09 \pm 0.23$ & $13.23 \pm 0.21$ \\
\hline $21: 5 n 3$ & $0.11 \pm 0.00$ & $0.19 \pm 0.00$ & $0.24 \pm 0.00$ \\
\hline $22: 5 n 6$ & $0.86 \pm 0.03$ & $0.27 \pm 0.01$ & $0.30 \pm 0.01$ \\
\hline $22: 5 n 3$ & $0.10 \pm 0.00$ & $1.83 \pm 0.05$ & $2.30 \pm 0.07$ \\
\hline $22: 6 n 3$ & $10.46 \pm 0.50$ & $21.33 \pm 0.45$ & $18.84 \pm 0.54$ \\
\hline subtotal & $22.63 \pm 0.86$ & $43.17 \pm 0.96$ & $39.84 \pm 1.02$ \\
\hline total & $99.35 \pm 3.34$ & $99.47 \pm 2.16$ & $99.44 \pm 2.48$ \\
\hline
\end{tabular}

